\title{
GLOBALIZATION AND ITS IMPACTS ON INTERNATIONAL DEVELOPMENT: A LONG-TERM HISTORICAL PERSPECTIVE
}

\section{MUHAMMED KURSAD OZEKIN}

\author{
(MA (King's College London), DPhil (University of Sussex)) \\ Usak University - Department of Political Science andInternational Relations, Turkey
}

\section{KEYWORDS: GLOBALIZATION, ECONOMIC GROWTH, UNEVEN DEVELOPMENT, CONVERGENCE.}

For citation: Ozekin M. (2019), Globalization And Its Impacts On International Development: A Long-Term Historical Perspective, Globalization And Business, №7, pp. 49-58. https://doi.org/10.35945/gb.2019.07.006

\section{INTRODUCTION}

The impact of globalization on international development is one of the most controversial issues of today's development discourse. Many studies come to different conclusions about this issue depending on how the questions are asked, and which data series are used. Broadly speaking, there are two distinct accounts about whether globalization brings international economic equality or not. The neoliberal school of thought or optimists argue that globalization creates an integrated world market in which prosperity, wealth and power are being diffused around the globe so that the globalization brings international equality in the long run. Particularly the rise of contemporary globalization both as a social process and a political project has brought about a considerable optimism concerning the role of global market forces in promoting growth, reducing poverty, and achieving economic development and prosperity particularly in developing countries. In this respect, the period from the late 1970s to the early 1990s witnessed a marked upsurge of highly optimistic neoliberal discourse both in development theory and practice (Ruckert, 2006).

However, probing into the empirical evidence, a growing intellectual doubt has been cast on the fundamental claim of the optimistic development discourse that globalization and fullscale market liberalization based on the neoclassical principle of comparative advantages leads to successful economic performance and overall growth in the world economy. In contrast so-called 'radical' school or pessimistic view argues that with the impact of globalization, the world is becoming more fragmented that income gap between the developed and developing countries is widening. For the pessimistic accounts, the development that the world economy experienced in the period from the early 1970s to the late 1990s, which could be termed the age of globalization, was considerably lower and unstable compared to the earlier period from the late 1940s to the early 1970s, which has been described as "the golden age of capitalism" (Kiely, 2005 and Nayyar, 2006). Moreover, not only has overall growth been lower, but also the degree of inequality in the world economy has also increased during the same period (see inter alia, UNCTAD, 1997 and Wade, 2001).

Rather than taking sides with either of these two camps, this study embraces a middle ground approach to the matter of globalization and development. Overall the study argues that globalization causes complex patterns of convergence and divergence across regions and between countries that its impacts cannot be observed at the same degree and effect in all ages and economies of the world. In this sense, it is argued that some countries benefit from it whereas some face economic losses, and so despite the relative industrial convergence and economic growth in developing countries inequality in international development is still persistent. In the light of this argument, this study aims to explore the impact of globalization on inequality in international development through two main stages. In the first stage, the study critically discusses the nexus between globalization and development by putting special emphasis on the complex patterns of development in the global economy, Particularly drawing on the works of Milanovic (2003) and Arrighi, Silver and Brewer (2003), the conceptualization of contemporary globalization either as a win-win situation or as a zero-sum game will be questioned based on the uneven, limited 
and asymmetric nature of economic globalization. In the second stage, the impact of globalization on international inequality is later explained through a long-term historical perspective. To this end, the relationship between globalization and development is situated in the wider historical context of the international capitalist system which has been in a phase of farreaching structural transformation for a long time. In doing so, the implications of globalization for development are explored in retrospect, focusing on the questions of uneven development in diverse industrialization processes. Finally, the last section concludes with a review of the arguments and key findings, and provided a broad view on the matter of Globalization and development.

\section{GLOBALIZATION AND INTERNATIONAL DEVELOPMENT: AN ECONOMIC OUTLOOK}

The buzzword globalization has been defined in many ways throughout the years ${ }^{1}$. In economic terms, globalization refers to the expansion and deepening of international trade, technology, capital and information. In other words, economic globalization means the flow of goods, services, investment, production, and technology across nations. This flow is inevitably associated with the liberalization of the markets, and international trade (Global Policy Forum, 2006). Another economic aspect of globalization is the integration of financial and commodity market, internationalization of production and increasing competitiveness. (Callaghan, 2002). In this regard, Globalization cannot be understood separately from the capitalist economic system of the world and should not be regarded as a driving force of international development per se.

Globalization creates an economic interdependence between countries on a global scale by increasing the volume and variety of cross-border transactions in terms of goods, services, capital and technology (Bhagwati, 2004). Within this explanation of globalization, free trade, capital mobility and technology transfer can be regarded as major economic dimensions of globalization which can be found in a greater or lesser degree all over the world. Each dimension has negative or positive economic impacts on both developed and developing countries depending on the case of each country.

\footnotetext{
${ }^{1}$ How to define and measure globalization is a quite controversial issue in development studies literature. As a multifaceted concept, globalization has economic, social, political aspects that move beyond basic indicators such as FDI movements and trade openness. Thus, given its multifaceted character, several indices have been developed to measure divergent aspects of globalization; for example, the CSGR Globalization Index (Lockwood and Redoano, 2005), the Maastrict Globalization Index (Martens and Raza, 2009), the KOF Index, (Dreher et al., 2008). Among them, the most often used index is the KOF Globalization index which see globalization as a process of creating networks through a variety of flows including capital, goods, people, information, ideas and etc.
}

According to neo-liberal point of view, international trade, as a one of the major economic dimensions of globalization, is more beneficial for poor economies because of three main reasons. First of all, free trade brings technology transfer which enables lower income economies to grow faster than higher income economies. (Weeks Gerschenkron 1962) Secondly, open trade policies have a bigger effect on the terms of trade of the countries integrating world economy than on countries already integrated (Lindert and Williamson, 2003). The third line of argument is that trade liberalization can facilitate the diffusion of knowledge and increase the steady-state income of lower income economies to a higher level.

In contrast, the globalization process and free trade have not shown their impacts at the same degree in all economies of the world. Contrary to what the international trade theory emphasizes, income distribution in developing countries is not improved with the rise in the volume of international trade. Depending on data derived from household surveys, Milanovic (2003) asserts that in poor countries upper income groups in social stratification are better off with open trade policies whereas lower income groups do not benefit from it adequately which leads to unequal income distribution within country. As the income level of poor countries increases, lower and middle-income groups begin to benefit from international trade. Therefore, initial income level of countries is a decisive factor in understanding to what extend will a country and social class benefit from open trade policies. In other words, with open trade policies, income distribution within poor countries could worsen, eventually leading to losses in overall income level of country. Therefore, it seems that countries having relatively abundant factors of production may benefit from free trade, whereas those having scarce factors may encounter problems in their economies.

The Capital mobility is another important dimension of globalization process. Both developed and developing countries benefit from foreign direct investment (FDI) and portfolio investments. FDI is a long term of investment in physical assets that creates employment opportunities whereas portfolio investments are short-term investments in financial assets which is more prone to create speculative impacts. Especially capital mobility in the form of portfolio investment might trigger the financial crises in vulnerable developing economies which do not have the stable financial market and well-established capital accumulation to handle potential crises. In this context, Woepking (2009) underlines that increasing liberalization of capital flow in developing countries makes their financial markets more liable to volatility and the crisis that brings along an increase in foreign debts and credits. By the same token, as Fischer (2003) further puts forward, integration of developing economies to global markets should be materialized gradually and with the establishment of necessary infrastructures. Otherwise their economies would be open to capital flow volatility, which might lead to an economic crisis, loss of output and unemployment. 
Over the past four decades, with the liberalization of international trade and capital flow, and the accompanying technological transfer, there has been a widespread convergence in the degree of industrialisation between rich and poor countries. However, over the same forty years there was virtually no income convergence between these states so that historical inequality in international development seems persistent. In fact, there is no doubt that as two of the most widely accepted aspects of the global economy, the restructuring of production and trade on a global scale has reshaped international divisions of labour to a considerable extent. Contrary to the post-war expansion of world capitalism in the 1950s and 1960s, the dismantling of production processes accompanied by dynamic growth in world trade has narrowed the gap between core and peripheral countries in terms of industrialization. The global spread of manufacturing capabilities to developing economies makes dichotomous denominations such as 'industrialized' and 'non-industrialized' increasingly untenable. Moreover, production is increasingly taking place in the framework of global value chains through which capital-, technology- and knowledge-intensive processes are dispersed to a greater number of countries, including developing ones. All these structural shifts become more obvious as time goes by. However, the question still remains: whether all these changes have brought economic and technological convergence between peripheral and core countries, and diminished the income gap between them in socio-spatial terms.

In response to this question, Arrighi et al. (2003, pp.1216) suggest that despite widespread convergence in levels of industrialization, the development gap and income disparity between the global south and global north have not been diminished but reproduced. Their findings reveal that the south as a whole converged with and even in some cases overtook the north in terms of industrialization levels. While the north's manufacturing sector comprised $28.9 \%$ of GDP in 1960 , it later incrementally descended to $24.5 \%$ by 1980 and to $19.8 \%$ by 1999 . On the other hand, the percentage of manufacturing in the south's GDP exhibits an opposite trend, ascending from $21.6 \%$ in 1960 to $24.3 \%$ in 1980 , with a slight fall to $23.3 \%$ in $1999^{2}$. Thus, the global south's percentage of GDP in manufacturing as a percentage of the global north's rose from $74.6 \%$ in 1960 to $99.4 \%$ and $118 \%$ in 1980 and 1998, respectively. However, Arrighi et al. empirically prove that the convergence in industrialization levels has not been accompanied by convergence in levels of income. As a proportion of the north's GNP per capita, GNP per capita in the global south has remained almost stagnant, with very slight changes from $4.5 \%$ in 1960 to $4.3 \%$ and $4.6 \%$ in 1980 and 1998 , respectively (Arrighi et al., 2003, pp.12-16).

Thus it is fair to discuss that the persistence of northsouth income disparity, despite apparent industrial convergence, reveals that the polarizing tendency of the world capitalist system is still at work and continuing to reproduce economic disparities between different sociospatial entities. Despite the bifurcation within the global south - due to conspicuous cases such as South Korea, Taiwan and more recently China - geographical asymmetries in income levels remain among the premier issues informing today`s global inequalities. In fact, the industrial convergence between rich and poor states has not been followed by convergence in the levels of income. The industrialization in Third World countries after 1980 increased the disparity of development levels and unevenness within the region. In this period, Sub-Saharan African and Latin American countries experienced major deterioration whereas East

2 The United Nations Industrial Development Organization's report reveals very similar figures regarding the period between 1980 and 2000. See UNIDO (2004, p.137).
Regions are separated as follows: 1. Asia, 2. Sub-Saharan Africa, 3. Middle East and North Africa, 4. Latin America, 5. Developing world, 6. Developing world, excluding China and India, 7. China and India, 8. Eastern Europe, 9. Non-industrialized world, 10.Industrialized world, 11. World. The developing world is the world excluding the industrialized world and Eastern Europe, and the non-industrialized world is the world excluding the developed (industrialized) world.

Source: World Bank, World Development Indicators. CD-ROMs, 2001.
Figure 1

Average per capita daily incomes of regions, 1960, 1980, and 2000 (1993 PPP dollars)

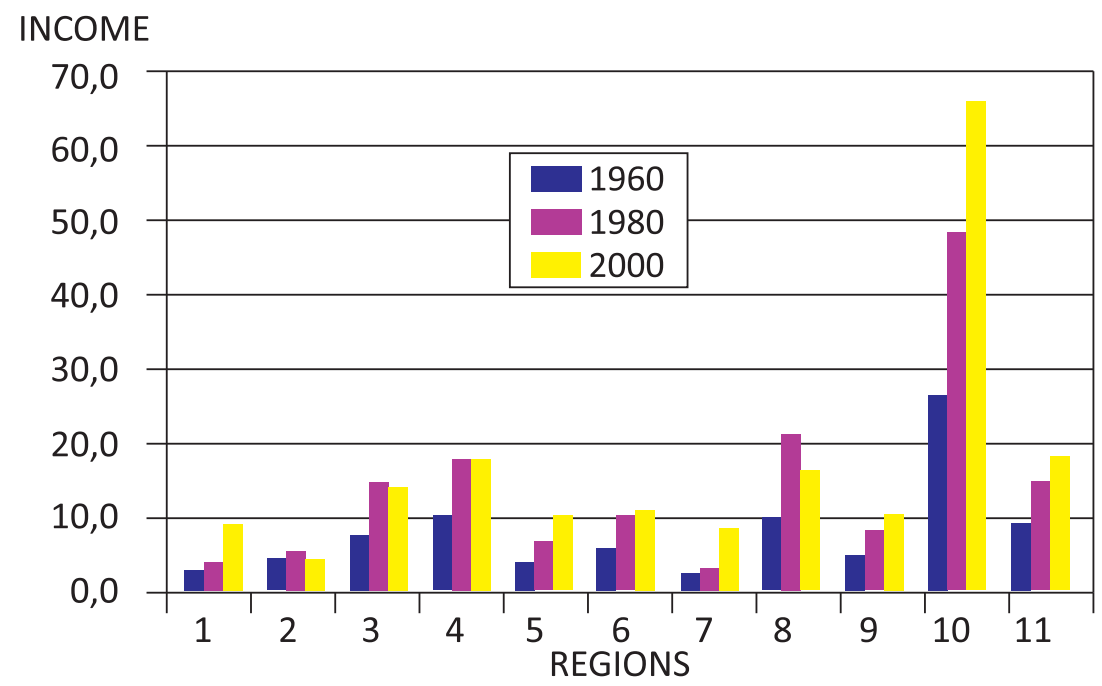


Asian ones developed considerably. Development disparities and rising unevenness created a bifurcation within Third World countries which creates a need to redefine historical North-South division. Nevertheless, despite the industrial convergence in Third World the structural North-South division maintains its importance as being a significant phenomenon in international development of global world.

The income divergence between developed and developing world can be retrospectively observed by assessing the average per capita daily incomes of regions between the years 1960 and 2000. As can be seen in World Bank global indicator of average per capita daily incomes, people of the industrialized countries earn the highest level of daily income in the world by comparison with the rest of the world. Although, Eastern Europe, Latin America, the Middle East, and North Africa have experienced a relative increase in their incomes, there is an ongoing income gap between developed and developing countries. Moreover, the income level of the industrialized world in 1960 still exceeds the other regions income levels in 2000.

In contrast the ongoing income gap, by giving weight to between country inequality rather than within country inequality in their measurement, Firebaugh and Goesling (2004) states that with the spread of industrialization throughout populous poor regions, globalization has decreased the inequality of income in the world. Their findings indicate that rapidly developing economies of China and South Asia are the major equalizing force in decreasing income inequality. However, Milanovic's (2002) study depending on household surveys indicated an increase in income inequality throughout the world. He stated (2005a) that rapidly developing economies of China and India may lead to misleading conclusions in measuring the effect of globalization

Figure 2

Global Output Growth Rate between 1951 and 2015 on the world income inequality. To Milanovic the between and within income inequality of several countries should be taken into consideration in order to improve the reliability of results about the impact of globalization on world income inequality. Moreover, the impact of globalization and open economic policies implemented by developing countries naturally generate different outcomes in each case. Some countries which have been able to govern globalization can benefit from it and others can face economic losses (Stiglitz, 2006).

Thus, the overall economic and social gains derived from the current wave of globalization have not presented simpler pattern for generalisations. First of all, with the exception of the 2000s, global growth rate shows a downward trend since the late 1960s (See, Figure 2). In fact, it is quite hard to reach a common view why this slowdown has occurred in the global economy, but it is fair to say that it has mostly originated from the overall economic slowdown in the developed economies. Probing into further empirical evidence reveals that over the last three decades, the slowdown of economic growth in developed world has been accompanied by an upward trend of growth in the developing world (See Table, 1). ${ }^{3}$ Thus, considering the overall growth trends both in the developed and developing economies, one might easily jump into the conclusion that the current phase of globalization has led to global convergence not only in terms of industrialisation but also in terms of global income. However, taking a closer look to the regional and country level indicators can help to gain further insight into the matter. In fact, looking into the recent data of the last three and half decades, two main feature stands out from the Table 1: first, there are varying

3 The 1970 s could also be considered as a period of convergence as the growth in the developed economies considerably decelerated due to the series of financial turmoil in global economy.

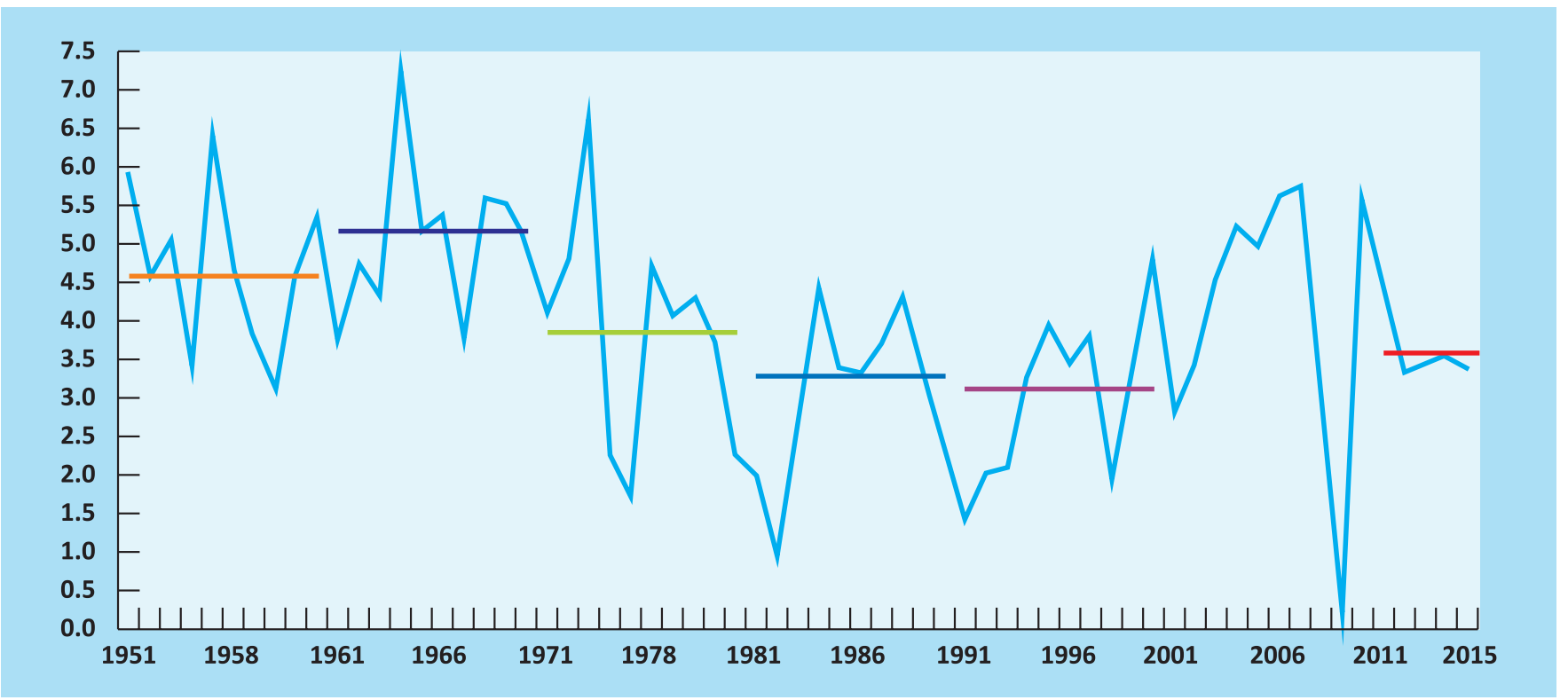

Source: UNCTAD (2016a) secretariat calculations, based on The Conference Board, Total Economy Database. 
periods of convergence and divergence between developed and developing economies and second, there is a growing bifurcation and disparity within the developing world as some regions and countries has grown much faster than others. As the Table 1 reveals, the first decade of the 2000s distinguished itself as a period of rapid and widespread growth in almost all developing world. However, a quick look to the current decade rather reveal that this might have been something anomaly since average annual growth rates in many parts of the developing world dropped down to the growth rates of the 1960 s and the 1970 s or even lower. More importantly, considering the period 1981-2018 in its entirety, developing regions and countries have presented divergent trajectories. Whereas East Asian economies, particularly China, exhibits a steady pattern of convergence, many parts of the developing world, namely West Asia and Latin America, have fallen
At this juncture, as most commonly used indicator of economic growth and welfare, GDP per capita could help us to assess the expansion of economies across and within regions but it remained limited when it comes to account for the well-being of nations and the quality of life of the world population. Thus, despite the relative improvements in overall growth indicators there remains in fact more work to be done in order to ensure more inclusive economic growth globally. Although extreme poverty has been declining globally thanks to the achievements in China and India, as the most populous countries in the world, poverty reduction has been quite unequal across regions and countries. Today, more than 830 million people live below the extreme poverty line of $\$ 1.90$ a day. When the poverty line is adjusted to the moderate poverty threshold from $\$ 1.90$ to $\$ 2.50$ a day, 1.8 million people- around 25 percent of the world population- fall below

Table 1

Growth of Real GDP Per Capita for Selected Regions and Countries, 1951-2018, (Average annual growth, per cent at PPP)

\begin{tabular}{|l|l|l|l|l|l|l|l|l|l|}
\hline & $1951-$ & $1981-$ & $1951-$ & $1961-$ & $1971-$ & $1981-$ & $1991-$ & $2001-$ & $2011-$ \\
1980 & 2018 & 1960 & 1970 & 1980 & 1990 & 2000 & 2010 & 2018 \\
\hline Developed Countries & 3.5 & 1.7 & 3.1 & 4.2 & 2.6 & 2.5 & 2.1 & 1.2 & 1.3 \\
\hline USA & 2.3 & 1.9 & 1.3 & 3.4 & 2.2 & 2.6 & 2.4 & 0.9 & 1.6 \\
\hline Developing Countries & 2.7 & 3.9 & 2.7 & 2.6 & 3.0 & 2.1 & 3.2 & 5.8 & 4.1 \\
\hline Africa & 1.8 & 1.3 & 1.5 & 1.9 & 1.2 & -0.4 & 0.7 & 3.0 & 1.9 \\
\hline Latin America & 2.6 & 1.3 & 2.4 & 2.4 & 3.0 & -0.4 & 1.6 & 2.4 & 1.2 \\
\hline Asia & 2.8 & 5.1 & 2.8 & 2.7 & 3.3 & 3.6 & 4.2 & 7.0 & 5.0 \\
\hline East Asia & 3.0 & 7.2 & 4.2 & 3.4 & 4.1 & 6.7 & 5.8 & 9.6 & 6.6 \\
\hline China & 2.3 & 7.7 & 4.1 & 2.7 & 3.1 & 6.5 & 6.2 & 11.1 & 7.3 \\
\hline South East Asia & 2.6 & 3.4 & 2.3 & 1.6 & 4.0 & 2.6 & 3.0 & 4.2 & 4.0 \\
\hline West Asia & 4.4 & 1.3 & 3.2 & 4.9 & 3.4 & -1.6 & 1.6 & 3.3 & 0.1 \\
\hline $\begin{array}{l}\text { Developing countries, } \\
\text { excl. China }\end{array}$ & 2.7 & 2.5 & 2.4 & 2.5 & 2.9 & 1.1 & 2.3 & 3.6 & 2.4 \\
\hline $\begin{array}{l}\text { Developing countries, } \\
\text { excl. East Asia and } \\
\text { South-East-Asia }\end{array}$ & 2.8 & 1.1 & 2.4 & 2.8 & 2.7 & -0.8 & 1.2 & 2.5 & 0.6 \\
\hline
\end{tabular}

Source: Authors calculation, based on the UNCTAD (2018) database.

behind in terms of GDP per capita growth. Thus, looking into the overall data, it is fair to argue that only certain part of the developing world - mostly confined to the East and South East Asian countries- has made noticeable strides in terms of narrowing the income gap with the developed economies. the poverty line (UNCTAD, 2016b, p.4). Again when two most populous countries in the developing world, namely China and India, are excluded, the extreme poverty still pose a global problem and strikes many parts of developing world including Asia, the Caribbean and in particular Sub-Saharan Africa. It is in

Figure 3 Extreme Poverty Around the world (Percentage of population) 2016

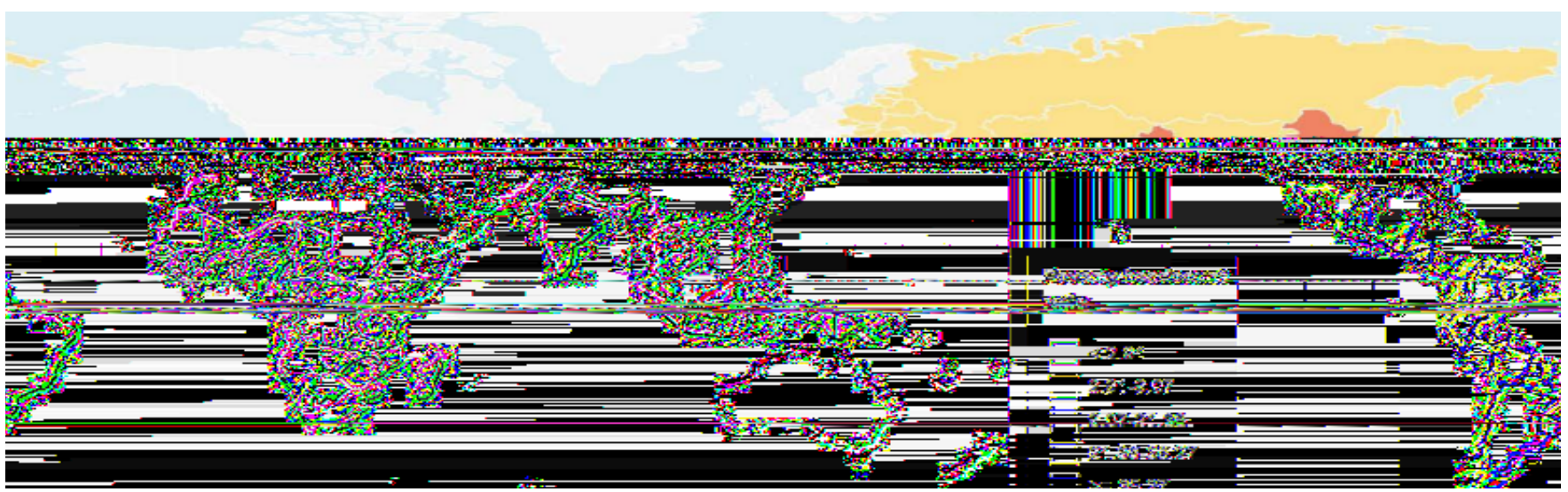

Sources: Derived from World Bank, Poverty and Equity Database. 
Table 2

Levels of GDP per capita and Interregional Spreads, 1000-1998

\begin{tabular}{|c|c|c|c|c|c|c|c|c|}
\hline \multicolumn{9}{|c|}{$\begin{array}{c}\text { Table } 2 \\
\text { Levels of GDP per capita and Interregional Spreads, }\end{array}$} \\
\hline & 1000 & 1500 & 1820 & 1870 & 1913 & 1950 & 1973 & 1998 \\
\hline Western Europe & 400 & 774 & 1232 & 1974 & 3473 & 4594 & 11534 & 17921 \\
\hline Western offshoots & 400 & 400 & 1201 & 2431 & 5257 & 9288 & 16172 & 26146 \\
\hline Japan & 425 & 500 & 669 & 737 & 1387 & 1926 & 11439 & 20413 \\
\hline Asia (excluding Japan) & 450 & 572 & 575 & 543 & 640 & 635 & 1231 & 2936 \\
\hline Latin America & 400 & 416 & 665 & 698 & 1511 & 2554 & 4531 & 5795 \\
\hline Eastern Europe \& former USSR & 400 & 483 & 667 & 917 & 1501 & 2601 & 5729 & 4354 \\
\hline Africa & 416 & 400 & 418 & 444 & 585 & 852 & 1365 & 1368 \\
\hline World & 435 & 565 & 667 & 867 & 1510 & 2114 & 4104 & 5709 \\
\hline $\begin{array}{l}\text { Inter-regional spreads- } \\
\text { Richest/poorest }\end{array}$ & $1.1: 1$ & $2: 1$ & $3: 1$ & $5: 1$ & $9: 1$ & $15: 1$ & $13: 1$ & $19: 1$ \\
\hline
\end{tabular}

Source: Maddison, The World Economy. A Millennial Perspective. Development Centre Studies, OECD, (2001).

fact hard to get up-to-date data covering all these regions, but according to the latest available, extreme poverty remains as a dire issue in Southern Asia and sub-Saharan Africa, with 80 per cent of population in these regions live less than $\$ 1.25$ a day. When examining the developing world as a whole, extreme poverty is not exclusively African and South-Asian problem: in the rest of the developing world such as Madagascar, Haiti and the Micronesian Island, the people living in extreme poverty constitutes the majority of the population (see, Figure 3 )

\section{GLOBALIZATION AND INTERNATIONAL DEVELOPMENT: A HISTORICAL OUTLOOK}

Globalization is not a new phenomenon in world history. Historical origins of modern globalization can be traced back to the second half of the 19th century. Therefore, the effect of globalization on international development should be considered with the historical perspective in order to comprehend the ongoing disparities in international development. Broadly, globalization process can be divided into three main historical periods.

The first wave of globalization or liberal era covers the period between 1870 and 1913.It was characterized by increasing international trade, unrestricted capital mobility under the gold Standard and international migration between Europe and the New World. The second period (19141950), covering two world wars, can be denominated as deglobalization era because of increasing restrictive practices toward international trade and capital with a widespread inflation and instability in Europe. The last period of 19502000 covers the golden age of capitalism (1950-1973) and the second wave of globalization or neo-liberal era (1973-2000 and onwards) which is characterized by more open trade regimes, increasing international financial flow, and more marketoriented economic policies in both industrialized, post-socialist and developing countries.
Since 1870 , the globalization process has caused complex patterns of economic convergence and divergence across regions of the world. For example, Maddison (2001) indicates that interregional disparities of GDP per capita between the Western Europe and the poor regions increased in the first wave of globalization period. As can be seen in Table 1, interregional disparities of GDP per capita between richest and poorest region increased from 5:1 in 1870 to 9:1 in 1913. The economic convergence of the first wave of globalization in fact occurred between the countries of Western Europe and the New World, but peripheral regions such as East Europe, Asia, and Latin America were left behind this process. (O'Rourke and Williamson, 2000). Therefore, the first period of modern globalization witnessed a convergence of GDP per capita and a decrease in international inequality across nations within the Atlantic Economy which underpinned the historical NorthSouth division of world economy.

The following period of "de-globalization" (1913-1950), characterized by two world wars, high inflation, instability and restrictive policies, reverted the trend of convergence between Atlantic Economy that had observed during the first wave of globalization. In this period global disparity between the richest and the poorest regions widened by the negative effects of the two world wars and the turbulence of the interwar period. (Solimano 2001) (also see table 2)

The next period of 1950-1973 which is labelled as the golden age of capitalism brought rapid growth, relative stability and declining inequality based on the regulated economy. Post world war economy was characterized by the balance of payment adjustment mechanism and Keynesian policies. During this period GDP in per capita gap between the poorest and the richest regions fell from 15:1 in 1950 to 13:1 in 1973 (see Table 2). Post world war period also witnessed a considerable convergence among western European Economies. Japan became a member of advanced capitalist economies. Some Asian countries such as Taiwan, South Korea, Hong Kong, Singapore experienced rapid growth rate in terms of GDP per capita (Salimano 2001). 
Hey day of golden age of capitalism was shaken by the collapse of the Bretton Woods system and the two international oil shocks of the 1970s which was followed by a slowdown in growth rates and an acceleration in inflation in the OECD countries. The second wave of globalization (19732000 and onwards) is characterized by pro-market economic policies and an increase in global financial flows. These policies were accompanied by a rise in global inequalities and regional disparities (Madison 2001). However, this period witnessed a convergence in Asia due to the high growth rate in Taiwan, Hong Kong, China and India (Salimano 2001). It can be also claimed that in the second wave of globalization period, weighted international inequality (weighted Gini coefficient for world) has decreased considerably with the rapid economic growth in China and India. However, it seems misleading to calculate international inequality in this way because the equalizing impact of rapid growth in these two countries, which possess the $45 \%$ of world population, do not enable us to understand the international inequalities rightly.

Milanovic (2001) has computed the weighted international inequality (1950-1998) with and without taking these two countries into account. As can be seen in Figure 4 since the 1960 's there has been a decline in the weighted international Gini coefficient (a 10\% decline, from 55.6 in 1965 to 50.1 in 1998).

Figure 4

Weighted International Inequality 1950-1998

Source: Milanovic, B. World Income Inequality in the Second Half of the Twenty Century mimeo, World Bank, (2001).

Figure 5

Weighted International Inequality without China and India 1950-1998

Source: Milanovic, B. World Income Inequality in the Second Half of the Twenty Century mimeo, World Bank, (2001).
However, the decline in the Gini reverses if China and India are excluded from the calculation. (see figure 5) With the exclusion of India and China, the weighted international Gini coefficient shows an increase since the 1980's which means that international inequality has been rising since the 1980's. Therefore, the rapid growth in Chinese and Indian economies which are faster than the growth rate of both world economy and economies of rich countries may mislead us. In fact, in the second wave of globalization period world witnessed a rapid economic growth in Asia which was accompanied by reduction in poverty. However, inequality has increased in Latin America, post-socialist Eastern Europe and former Soviet Union and the importance of these regions in world economy has relatively declined. (Salimano 2001)

To sum up when we consider the overall globalization process from 1870 to 2000 , it can be claimed that globalization brings remarkable improvements in living conditions and human development (IMF, 2000). However, it has also caused complex patterns of economic convergence and divergence across regions of the world. It has generated different outcomes for each country that some countries have benefited from it and some faced economic losses. Since 1870, the world has witnessed unprecedented increase in material wealth, growth and experienced dramatic technical development. However, this was also a period of large disparities in income per head
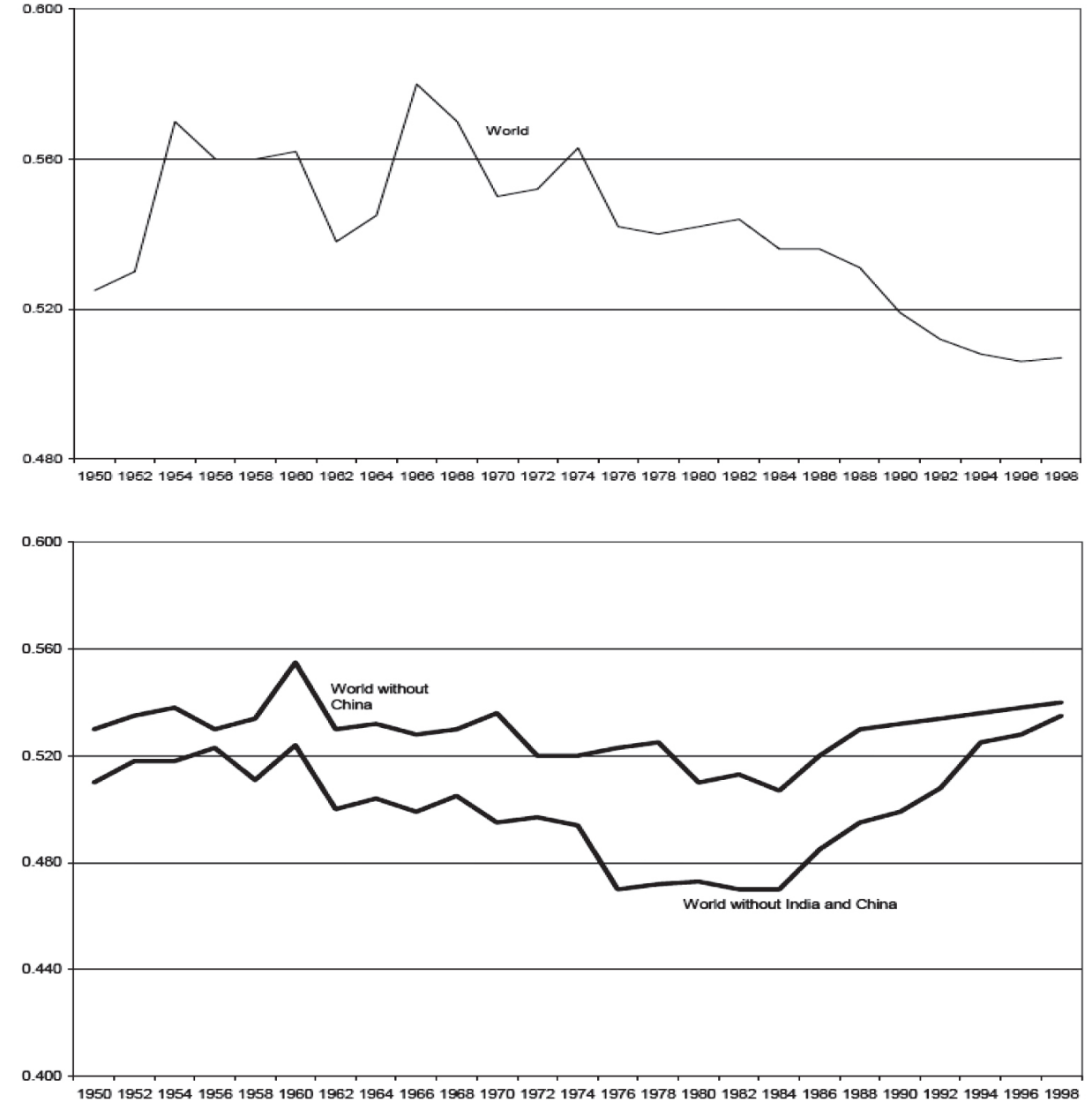
and living standards across countries and regions of the world and despite the economic growth in the developing regions of the world, inequality in international development is still persistent that today one billion people living in developed countries earn 80 percent of the world domestic product whereas the remaining 20 percent is distributed between five billion people who live in developing countries (Rizvi, 2005, p. 2)

\section{CONCLUSION}

Overall globalization process (second stage) and its impact on international development (first stage) shows that globalization causes complex patterns of convergence and divergence across regions and between countries that its impacts cannot be observed at the same degree in all economies of the world. In the first wave of globalization, economic convergence occurred within Atlantic Economy (Europe and the New World) and it did not extend to Central, Eastern European, Asian and Latin American countries.
After the rapid growth in golden age of capitalism, regional convergence was observed within Asia due to the economic growth in South Korea, Taiwan, Hong Kong, India and China. Despite the claims of narrowing international income gap with the equalizing effect of two rapidly growing Asian giant economies India and China weighted international Gini coefficient indicates an ongoing increase since the 1980's.

Moreover, despite the industrialization of Third World with market friendly economic policies, industrial convergence between developed and developing countries has not been followed by an income convergence (first stage). Therefore, expected positive impacts of open economic policies and globalization on international inequalities did not materialize adequately on a global scale. Whereas East Asian countries experienced high growth rates Sub-Sahara African and Latin American countries suffered from economic deterioration. Despite the growth and the improvement of living conditions in developing countries, uneven development and ongoing international economic inequality continues to be a persistent phenomenon of international development.

\section{REFERENCES:}

1. Arrighi G., Silver B. J., and Brewer B. D., (2003). Industrial Convergence, Globalization, and the Persistence of the North-South Divide. Studies in Comparative International Development, 38 (1), pp. 3-31.

2. Bhagwati, J., (2004). In Defense of Globalization. Oxford: Oxford University Press.

3. Callaghan, J., (2002). Social Democracy and Globalization: The Limits of Social Democracy in Historical Perspective. British Journal of Politics and International Relations, 4(3), pp. 429-451.

4. Dreher, A., N. Gaston and P. Martens, (2008). Measuring Globalization - Gauging Its Consequences. Berlin: Springer.

5. Firebaugh, G. and Goesling, B., (2004). Accounting for the Recent Decline in Global Income Inequality. American Journal of Sociology, 110(2), pp. 283-312

6. Fischer, S., (2003). Globalization and Its Challenges. The American Economic Review, 93 (2), pp.1-30.

7. Kiely R., 2005. Empire in the Age of Globalization: US Hegemony and Neo-liberal Disorder. London: Pluto Press.

8. Lockwood, B. and M. Redoano, (2005). The CSGR Globalization Index: An Introductory Guide', Working Paper 155, Warwick: Centre for the Study of Globalization and Regionalisation.

9. Maddison, A., (2001). The World Economy. A Millennial Perspective. Development Centre Studies, OECD.

10. Martens, P. and M. Raza, (2009). Globalization in the 21st Century: Measuring Regional Changes in Multiple Domains. Integrated Assessment, 9(1), pp.1-18.

11. Milanovic, B., (2001). World Income Inequality in the Second Half of the Twenty Century . Mimeo, World Bank.

12. Milanovic, B., (2003). Can We Discern the Effect of Globalization and Income Distribution? Evidence from Household Budget Surveys. Policy Research Working Paper, No. 2876.

13. Milanovic, B., (2005). Worlds Apart: Measuring International and Global Inequality. Princeton: Princeton University Press. 14. Nayyar, D., (2006). Globalization, History and Development: A Tale of Two Centuries. Cambridge Journal of Economics, 30(1), pp. 137-159.

15. O'Rourke, K.H. and Williamson J.G., (2000). Globalization and History. The Evolution of a Nineteenth Century Atlantic Economy. Massachusetts: The MIT Press.

16. Ruckert, A., (2006). Towards an Inclusive-Neoliberal Regime of Development: From the Washington to the Post- Washington Consensus. Labour, Capital and Society, 39(1), pp.34- 67.

17. Stiglitz, J. E., (2008). Making Globalization Work. Economic and Social Review, 39(3), pp 171-190.

18. Solimano A., (2001). The Evolution of World Income Inequality: Assessing the Impact of Globalization. CEPAL - SERIE:United Nations Publication.

19. UNCTAD, (1997). Trade and Development Report 1997, New York and Geneva: United Nations Publication. 20. UNCTAD, (2016a).Trade and Development Report 2016, New York and Geneva: United Nations Publication. 
21. UNCTAD, (2016b). Development and Globalization Facts and Figures, New York and Geneva: United Nations Publication. 22. Wade, R., (2001). Is Globalization Making World Income Distribution More Equal?. LSEDESTIN Working Paper No 01-01. London: London School of Economics, Development Studies Institute.

23. Weeks J., (1999). The Expansion of Capital and Uneven Development on a World Scale. Centre for Development Policy \& Research (CDPR). SOAS University of London.

24. International Monetary Fund, (2000.) Globalization: Threat or Opportunity? [online] Available at <http://www.imf.org/ external/np/exr/ib/2000/041200to.htm> [Accessed 23 July 2018].

25. Rizvi, H., 2005. Globalization Driving Inequality, UN Warns. [online] Available at: <http://globalpolicy.org/component/ content/article/218-injusticeand-inequality/46548.pdf> [Accessed 23 July 2018].

26. Woepking, J., (2008). International Capital Markets and Their Importance, The University of Iowa Center for International Finance and Development. [online] Available at: <http://www.uiowa.edu/ifdebook/ebook2/contents/part3-II.shtml> [Accessed 23 July 2018].

27. Global Policy Forum, (2006). [online] Available at: <http://www.globalpolicy.org/globalization/globalization-of-theeconomy-2-1/generalanalysis-on-globalization-of-the-economy.html> [Accessed 23 July 2018].

28. World Bank, World Development Indicators. [online] Available at: <http://search.worldbank.org/data?qterm=World+Devel opment+Indicators\&language=EN\&format=html> [Accessed 23 July 2018]. 


\section{GLOBALIZATION AND ITS IMPACTS ON INTERNATIONAL DEVELOPMENT: A LONG-TERM HISTORICAL PERSPECTIVE}

\section{MUHAMMED KURSAD OZEKIN}

(MA (King's College London), DPhil (University of Sussex))

Usak University - Department of Political Science and International Relations, Turkey

\section{KEYWORDS: GLOBALIZATION, ECONOMIC GROWTH, UNEVEN DEVELOPMENT, CONVERGENCE.}

For citation: Ozekin M. (2019), Globalization And Its Impacts On International Development: A Long-Term Historical Perspective, Globalization And Business, №7, pp. 49-58. https://doi.org/10.35945/gb.2019.07.006

\section{SUMMARY}

The nexus between globalization and international development is one of the most debatable issues in today's development literature. Broadly, there are two camps: the diffusionist accounts of neoliberal school of thought or what we might call optimists and the so-called radical school of thought or pessimists. Rather than taking sides with either of these two camps, this study embraces a middle ground approach to the matter of globalization and development. Overall, it argues that globalization causes complex patterns of convergence and divergence across regions and between countries that its impacts cannot be observed at the same degree and effect in all ages and economies of the world. In the light of this argument, this study aims to explore the impact of globalization on the unevenness of international development through two main stages. In the first stage, the study critically discusses the nexus between globalization and development by putting special emphasis on the complex patterns of development in the global economy, To that end, the conceptualization of contemporary globalization either as a win-win situation or as a zero-sum game is questioned based on the uneven and asymmetric nature of economic globalization. Later in the second stage, the relationship between globalization and development is situated in a wider historical context of the international capitalist system which has been in a phase of far-reaching structural transformation for a long time. In doing so, the implications of globalization for development are explored in retrospect, focusing on the question of uneven development throughout the history. 